\title{
Prevalence of anemia during pregnancy and its association with adverse perinatal outcomes in Madhya Pradesh, India
}

\author{
Divya Sinha $^{1}$, Swati Shrivastava ${ }^{2 *}$
}

\begin{abstract}
${ }^{1}$ Department of Obstetrics and Gynecology, G. R. Medical College, Gwalior, Madhya Pradesh, India
${ }^{2}$ Department of Biochemistry, Government Medical College, Datia, Madhya Pradesh, India
\end{abstract}

Received: 26 January 2019

Accepted: 30 January 2019

\section{*Correspondence:}

Dr. Swati Shrivastava,

E-mail: swatishrivastava574@gmail.com

Copyright: () the author(s), publisher and licensee Medip Academy. This is an open-access article distributed under the terms of the Creative Commons Attribution Non-Commercial License, which permits unrestricted non-commercial use, distribution, and reproduction in any medium, provided the original work is properly cited.

\section{ABSTRACT}

Background: The prevalence of anemia in India is increasing day by day and covers almost one third population. Anemia during pregnancy leads many perinatal complications such as miscarriage, abortion and still birth. So, the aim of the study was to determine prevalence of anemia during pregnancy and its association with adverse perinatal outcomes in region of Madhya Pradesh.

Methods: The study population consisted of 15-49 years women of reproductive age group from the state Madhya Pradesh, India, which were taken from the National Family Healthy Survey-4 (2015-16). Various perinatal outcomes along with age and residence was cross tabulated and frequencies were generated. The chi-square statistic was used to test the significance.

Results: In severe anaemic women prevalence of miscarriage $(74.0 \%)$ was statistically significantly higher $(\mathrm{p}<0.05)$ as comparison to other forms of anemia. Also, in the age group 25-29 years and rural population prevalence of miscarriage $(40 \%$ and $55 \%)$ was highly significant $(\mathrm{p}<0.001)$ as comparison to other age group and urban population. Conclusions: The severity of anemia is directly proportional to poor and adverse perinatal outcomes in pregnancy.

Keywords: Anemia, Pregnancy, Perinatal outcomes

\section{INTRODUCTION}

Anemia during pregnancy is a public health problem especially in developing countries and is associated with adverse outcomes in pregnancy. ${ }^{1}$ World Health Organization (WHO) has defined anaemia in pregnancy as the haemoglobin $(\mathrm{Hb})$ concentration of less than $11 \mathrm{~g} / \mathrm{dl} .^{2}$

Maternal anemia leads to many adverse effects on the foetus and can lead complications such as low birth weight, preterm deliveries, developmental anomalies and even neonatal death are some of them. ${ }^{3}$ The causes of anaemia during pregnancy in developing countries aremultifactorial; these include micronutrient deficiencies of iron, folate, and vitamins A and B12 and anaemia due to parasitic infections such as malaria and hookworm or chronic infections like TB and HIV.4-8

Patients with anemia present similar clinical symptoms such as fatigue, breathlessness, dizziness, and headache. ${ }^{9}$ Anemia also increases the susceptibility to different kinds of infections and impairs the work capacity. ${ }^{10}$ Severity of symptom caused by anemia is paralleled with the severity of anemia. ${ }^{11}$ Severe anemia may predispose to infection and heart failure, while severe anemia during pregnancy may significantly contribute to both maternal mortality and morbidity. ${ }^{12,13}$ Severe maternal anemia carries a significant risk of haemorrhage and infection in mothers, reduces the resistance to blood loss causing maternal 
death and place women at higher risk of death during delivery and the period following childbirth. ${ }^{14,15}$ Maternal anemia may also increase the risk of adverse pregnancy outcomes, such as preterm birth, low birth weight, small size for gestational age infants, perinatal death, and anemia in infancy. ${ }^{16-20}$ So the main objective of the study was to found out prevalence of anemia during pregnancy and its association with adverse perinatal outcomes in region of Madhya Pradesh.

\section{METHODS}

The National Family Health Survey (NFHS), the fourth in the NFHS series was conducted in year 2015-16, provides information on population, health, and nutrition for India and each state and union territory. All four NFHS surveys have been conducted under the stewardship of the Ministry of Health and Family Welfare (MoHFW), Government of India. NFHS-4 fieldwork for Madhya Pradesh was conducted in all 50 districts of the state and collected information from 52,042 households, 62,803 women age 15-49. The study subjects were evaluated for the standard routine antenatal care and its service utilization. The haemoglobin report done in the present pregnancy was used to categorise the study subjects. A pregnant woman was considered anemic if haemoglobin was $<11 \mathrm{~g} / \mathrm{dl}$. Severity of anaemia was measured as follows: mild if $\mathrm{Hb}$ was $9.0-10.9 \mathrm{~g} / \mathrm{dl}$; moderate if $\mathrm{Hb}$ was $7.0-8.9 \mathrm{~g} / \mathrm{dl}$; and severe if $\mathrm{Hb}$ was $<7.0 \mathrm{~g} / \mathrm{dl}$. The reference group was taken as the first category for the age group, and last category for all other predictors. The data on predictors were taken on age (grouped), type of place of residence, anaemia level vs miscarriage, abortion and still birth status.

\section{Statistical analysis}

Prevalence of anaemia was expressed in percentage and Chi square test was used as a test of significance. $P$ value of 0.05 and less was considered as statistically significant.

\section{RESULTS}

In the present study, the prevalence of anemia was found in Madhya Pradesh was 54.3\%. The Above table shows the distribution of anemia status in different age group of the state of Madhya Pradesh. In the reproductive age group, the maximum anaemic women are found in 20-24 age groups as followed by $15-19$ years. The overall anemia of Madhya Pradesh was $54.3 \%$ in all reproductive age group of the women followed by $45.6 \%$ non-anaemic women in the same group. The both groups are statistically significant.

Table 1: The prevalence of anemia in different age group women.

\begin{tabular}{|c|c|c|c|c|}
\hline \multirow{2}{*}{ Age in 5-year groups } & \multicolumn{2}{|c|}{ Anaemia Status } & \multirow{2}{*}{$\begin{array}{l}\text { Total } \\
(n=128372)\end{array}$} & \multirow{2}{*}{$\chi^{2}$ (p-value) } \\
\hline & Anaemia, $n=69747(54.3 \%)$ & Non-anaemia $n=58625(45.6 \%)$ & & \\
\hline $15-19$ & $427(67.35 \%)$ & 207 & 634 & \multirow{8}{*}{$\begin{array}{l}228.8 \\
(<0.001)\end{array}$} \\
\hline $20-24$ & $6390(60.55 \%)$ & 4163 & 10553 & \\
\hline $25-29$ & $11358(55.93 \%)$ & 8950 & 20308 & \\
\hline $30-34$ & $12204(52.39 \%)$ & 11092 & 23296 & \\
\hline $35-39$ & $12907(52.92 \%)$ & 11484 & 24391 & \\
\hline $40-44$ & $12813(53.68 \%)$ & 11056 & 23869 & \\
\hline $45-49$ & $13648(53.90 \%)$ & 11673 & 25321 & \\
\hline Total & $69747(54.33 \%)$ & 58625 & 128372 & \\
\hline
\end{tabular}

Table 2: Association of adverse perinatal pregnancy outcomes in different age groups women.

\begin{tabular}{|c|c|c|c|c|}
\hline Age in 5-year groups & Miscarriage & Abortion & Stillbirth & $\chi^{2}(\mathrm{p}$-value $)$ \\
\hline $15-19$ & $25(1.2 \%)$ & $0(0.0 \%)$ & $7(2.4 \%)$ & \multirow{7}{*}{$84.4(<0.001)$} \\
\hline $20-24$ & $531(26.0 \%)$ & $100(15.2 \%)$ & $81(27.6 \%)$ & \\
\hline $25-29$ & $830(40.7 \%)$ & $245(37.2 \%)$ & $100(34.1 \%)$ & \\
\hline $30-34$ & $390(19.1 \%)$ & $185(28.1 \%)$ & $62(21.2 \%)$ & \\
\hline $35-39$ & $165(8.1 \%)$ & $81(12.3 \%)$ & $30(10.2 \%)$ & \\
\hline $40-44$ & $65(3.2 \%)$ & $37(5.6 \%)$ & $13(4.4 \%)$ & \\
\hline $45-49$ & $35(1.7 \%)$ & $10(1.5 \%)$ & $0(0.0 \%)$ & \\
\hline
\end{tabular}

Authors also found that in the age group 25-29 years the prevalence of miscarriage was more $(40.7 \%$, highly significant $\mathrm{p}<0.001)$ as comparison to other age groups. (Table 2). The above table shows the distribution and pattern of pregnancy in Madhya Pradesh as per reproduction age group. Table 2 highlights that the maximum chance of miscarriage $40.7 \%$ was found in age of 25-29 years as followed by the $26 \%$ in $20-24$ years. 
The abortion was found maximum in 25-29 age group and maximum still births were also found in same age group. The study showed that the prevalence of anemia was more in rural population than urban population. (Table 3). The data showed that in severe anaemic women prevalence of miscarriage $(74.7 \%)$ was statistically significantly higher $(\mathrm{p}<0.05)$ as comparison to other forms of anemia as shown in Table no 4 . The above table shows that the level of anemia is distributed in three categories i.e. severe, moderate and mild. The above table shows the distribution of pregnancy outcome versus anemia level which shows that the maximum miscarriage was found in severe anaemic women in Madhya Pradesh as followed by mild anaemic women.

Table 3: Association of prevalence of anemia with respect to place of residence.

\begin{tabular}{|l|l|l|l|l|}
\hline \multirow{2}{*}{$\begin{array}{l}\text { Place of } \\
\text { residence }\end{array}$} & Anemia status & Total & $\begin{array}{l}\chi^{2} \\
\text { (p-value) }\end{array}$ \\
\cline { 1 - 3 } Urban & $\begin{array}{l}\text { Not } \\
\text { anaemic } \\
(51.0 \%)\end{array}$ & $\begin{array}{l}15854 \\
(49.0 \%)\end{array}$ & 32377 & \\
\hline Rural & $\begin{array}{l}53224 \\
(55.4 \%)\end{array}$ & $\begin{array}{l}42771 \\
(44.6 \%)\end{array}$ & 95995 & $\begin{array}{l}189.8 \\
(<0.001)\end{array}$ \\
\hline Total & 69747 & 58625 & 128372 & \\
\hline
\end{tabular}

\section{DISCUSSION}

Maternal anemia is considered as risk factor for poor pregnancy outcomes, and it threatens the life of fetus. Available data from India indicate that maternal and fetal morbidity rates are higher in anemicwomen. ${ }^{21-23}$ In this study, in severe anaemic women prevalence of miscarriage $(74.7 \%)$ was statistically significantly higher $(\mathrm{p}<0.05)$ as comparison to other forms of anemia. Also the prevalence of anemia was more in rural population than urban population. This may be because during pregnancy there is increased iron demand and poor nutrition, poverty, lack of awareness, inadequate access to health services, illiteracy so women becomes severely anemic and resulted in poor pregnancy outcomes. There is a substantial amount of evidence showing that maternal iron deficiency anemia early in pregnancy can result in low birth and still birth subsequent to preterm delivery. ${ }^{24}$ There was a significant statistical association between anemia and complications during pregnancy in the present study, which is similar to the study conducted by Nair et al. ${ }^{25}$ This study showed that in the age group 25 29 years the prevalence of miscarriage was more $(40.7 \%$, highly significant $\mathrm{p}<0.001$ ) as comparison to other age groups which was also common reproductive age in the M.P. region. An age group of above 30 years was found to be predominant in a study by Cheema et al. ${ }^{26}$

In a study Dey et al, reported that pregnant, under nutritious, and poorest women are at high risk of anaemia. ${ }^{27}$ Urban women are also at high risk; however, higher educated women are at low risk of anaemia. This is in accordance with our findings.
The prevalence of anemia in this study was found out to be $54.33 \%$.A similarly high rate of anemia was found in a large Indian study including 11 states, where the prevalence of anemia was $87 \%$ among 4,775 pregnant women at more than 20 weeks of gestation. ${ }^{28}$ The prevalence of anemia among pregnant women in other developing countries ranges from $35 \%$ to $81 \% .{ }^{29-30}$ The etiology of anemia during pregnancy among women in developing countries is multifactorial and varies by geographic region. The primary cause of anemia during pregnancy worldwide is iron deficiency secondary to chronic inadequate dietary intake and menstruation, heightened by the physiologic demands of the fetus and maternal blood volume expansion during pregnancy. With limited resources available to address public health problems, knowledge of the local etiological factors responsible for anemia is crucial in order to design appropriate prevention and treatment strategies. ${ }^{31}$

\section{CONCLUSION}

It can be concluded that severity of anemia is directly proportional to poor and adverse perinatal outcomes in pregnancy.

\section{Funding: No funding sources Conflict of interest: None declared \\ Ethical approval: The study was approved by the Institutional Ethics Committee}

\section{REFERENCES}

1. Black RE, Victora CG, Walker SP, Bhutta ZA, Christian P, De Onis M, et al. Maternal and child undernutrition and overweight in low-income and middle-income countries. Lancet, 2013;382(9890):427-51.

2. World Health Organization. Iron deficiency anemia. assessment, prevention, and control. A guide for programme managers. 2001:47-62.

3. Vanamala VG, Aruna Rachel A ,Pakyanadhan S, Somavathi. Incidence and outcome of anemia in pregnant women: a study in a tertiary care centre. Int J Reprod Contracept Obstet Gynecol. 2018;7(2):46266.

4. Msuya SE, Hussein TH, Uriyo J, Sam NE, StrayPedersen B. Anaemia among pregnant women in northern Tanzania: prevalence, risk factors and effect on perinatal outcomes. Tanzania $\mathbf{J}$ Health Res.2011;13(1) 33-9.

5. Okube OT, Mirie W, Odhiambo E, Sabina W and Habtu M. Prevalence and Factors Associated with Anaemia among Pregnant Women Attending Antenatal Clinic in the Second and Third Trimesters at Pumwani Maternity Hospital, Kenya. Open J Obstet Gynecol, 2016;6(01):16-27.

6. Brooker S, Hotez PJ, Bundy DAP, Hookwormrelated anaemia among pregnant women: a systematic review," PLOS Neglected Trop Dis. 2008;2(9):291. 
7. McClure EM, Meshnick SR, Mungai P, Malhotra I, King CL, Goldenberg RL et al. The association of parasitic infections in pregnancy and maternal and fetal anemia: a cohort study in coastal Kenya. PLOS Neglected Trop Dis. 2014;8(2):2724.

8. Ononge S, Campbell O, Mirembe F. Haemoglobin status and predictors of anaemia among pregnant women in Mpigi, Uganda. BMC Res Notes. 2014;7(1):712.

9. Alem M, Enawgaw B, Gelaw A, Kena T, Seid M, Olkeba Y. Prevalence of anemia and associated risk factors among pregnant women attending antenatal care in Azezo Health Center Gondar town, Northwest Ethiopia. J. Interdiscip Histopathol. 2013, 1(3):137-44.

10. Balarajan Y, Ramakrishnan U, Özaltin E, Shankar AH, Subramanian SV. Anaemia in low-income and middle-income countries. Lancet. 2011;378(9809):2123-35.

11. Adamu AL, Crampin A, Kayuni N, Amberbir A, Koole O, Phiri A, et al. Prevalence and risk factors for anemia severity and type in Malawian men and women: urban and rural differences. Population Health Met. 2017;15(1):12.

12. Kassebaum NJ, Jasrasaria R, Naghavi M, Wulf SK, Johns N, Lozano R, et al. A systematic analysis of global anemia burden from 1990 to 2010. Blood. 2014;123(5):615-24.

13. Toteja GS, Singh P, Dhillon BS, Saxena BN, Ahmed FU, Singh RP et al. Prevalence of anemia among pregnant women and adolescent girls in 16 districts of India. Food Nutri Bullet. 2006;27(4):311-5.

14. Hashim N, Farooqi M, Naqvi S, Jaffery HF, Anemia; moderate to severe during pregnancy. Prof Med J. 2014,21(2):247-52.

15. Ransom, E.I.; Elder, L.K. Nutrition of Women and Adolescent Girls: Why It Matters; Population ReferenceBureau: Washington, DC, USA, 2003. Available

at https://www.prb.org/nutritionofwomenandadolescent girlswhyitmatters/

16. Rahmati S, Delpisheh A, Parizad N, Sayehmiri K, Maternal anemia and pregnancy outcomes: A systematic review and meta-analysis. Int $\mathbf{J}$ Pediatr. 2016;4(8):3323-3342.

17. Lone FW, Qureshi RN, Emanuel F. Maternal anaemia and its impact on perinatal outcome. Trop Med Int Health. 2004;9(4):486-490.

18. Gomes da Costa A, Vargas S, Clode N, Graça LM. Prevalence and risk factors for iron deficiency anemia and iron depletion during pregnancy: A prospective study. Acta Med Port. 2016:29(9):514-8.

19. Stevens GA, Finucane MM, De-Regil LM, Paciorek CJ, Flaxman SR, Branca F et al, Nutrition Impact Model Study Group. Global, regional, and national trends in haemoglobin concentration and prevalence of total and severe anaemia in children and pregnant and non-pregnant women for 1995-2011: a systematic analysis of population-representative data. Lancet Global Health. 2013;1(1):e16-25.

20. Chang SC, O'Brien KO, Nathanson MS, Mancini J, Witter FR. Hemoglobin concentrations influence birth outcomes in pregnant African-American adolescents. Journal Nutri. 2003;133(7):2348-55.

21. Kalaivani K. Prevalence and consequences of anaemia in pregnancy. Indian J Med Res. 2009;130(5):627-33.

22. Ivan EA, MangaiarkkarasiA.. Evaluation of anaemia in booked antenatal mothers during the last trimester. J Clin Diagn Res. 2013;7(11):2487-90.

23. Singh R, Chauhan R, Nandan D, Singh H, Gupata SC, Bhatnagar M. Morbidity profile of women during pregnancy: A hospital record-based study in Western UP. IJCH. 2012;24(4):342-6.

24. Allen LH. Anaemia and iron deficiency: Effects on pregnancy outcome. Am J Clin Nutr 2000;71(5):1280-4.

25. Nair M, Choudhury MK, Choudhury SS, Kakoty SD, Sarma UC, Webster P, et al. Association between maternal anaemia and pregnancy outcomes: A cohort study in Assam, India. BMJ Glob Health 2016;1:e000026.

26. Cheema HK, Bajwa BS, Kaur K, Joshi H. Prevalence and possible risk factors of anaemia in different trimesters of pregnancy. IJCMR. 2016;3(4):1194-7.

27. Dey S, Goswami S, Goswami M. Prevalence of anaemia in women of reproductive age in Meghalaya: a logistic regression analysis. Turk J Med Sci. 2010;40(5):783-9.

28. Seshadri S. Prevalence of micronutrient deficiency particularly of iron, zinc and folic acid in pregnant women in South East Asia. Br J Nutr. 2001;85(2):S87-92.

29. Adam I, Khamis AH, Elbashir MI. Prevalence and risk factors for anaemia in pregnant women of eastern Sudan. Trans R Soc Trop Med Hyg. 2005; 99(10):739-43.

30. Ayoya MA, Spiekermann-Brouwer GM, Traore AK, Stoltzfus RJ, Garza C. Determinants of anemia among pregnant women in Mali. Food Nutr Bull. 2006; 27(1):3-11.

31. Baig-Ansari N, Badruddin SH, Karmaliani R, Harris $\mathrm{H}$, Jehan I, Pasha O, et al Anemia prevalence and risk factors in pregnant women in an urban area of Pakistan. Food Nutr Bull. 2008;29(2):132-9.

Cite this article as: Sinha D, Shrivastava S. Prevalence of anemia during pregnancy and its association with adverse perinatal outcomes in Madhya Pradesh, India. Int J Reprod Contracept Obstet Gynecol 2019;8:845-8. 